\title{
A KÜLÖNLEGES MENTÉSI FELSZERELÉSEK BIZTONSÁGOS HASZNÁLATÁNAK ELEMZÉSE STATISZTIKAI MÓDSZEREKKEL, I. RÉSZ
}

\section{STATISTICAL METHODS FOR ANALYSIS OF SAFE USE OF SPECIAL RESCUE EQUIPMENT, PART I.}

\author{
JACKOVICS Péter \\ (ORCID: 0000-0002-1809-029X) \\ peter.jackovics@katved.gov.hu;
}

\begin{abstract}
Absztrakt
A katasztrófák és a balesetek fokozódó extrémitása miatt a mentési müveletek egyre összetettebbé váltak, ez pedig mind elméleti mind pedig gyakorlati szempontból jobban felkészült mentési szakszemélyzetet kíván meg. Komoly problémát jelent, hogy a különleges mentéseknél alkalmazott eszközök használatának módszerei sok esetben csupán „Szájhagyomány” alapján terjednek, miközben a gyártók által a kifejlesztett eszközpark viszont dinamikusan fejlödik. A mentési felszerelések ilyen mértékü változása a kötéltechnikával végzett mentések esetében is jól megfigyelhetö, ahol a biztonságos eszközhasználatnak fokozottan kell érvényesülni.

A tanulmány célja, hogy egy erre a célra tervezett kérdőives kutatás eredményeinek matematikai statisztikai feldolgozása alapján egyfelöl megválaszolja azt a kérdést, hogy a felhasználók hogyan itélik meg három kiválasztott konkrét kötéltechnikai eszköz biztonságos használhatóságát, másrészt pedig erre támaszkodva biztonságnövelő javaslatokat fogalmazzon meg ezen eszközök használatával kapcsolatban. A tanulmányom első részében a Mann-Whitney próba és a Spearman-féle rangkorreláció eredményeit elemzem.
\end{abstract}

Kulcsszavak: Kötéltechnika, Mentési felszerelés, Statisztika, Biztonság, Spearmanféle korreláció

\begin{abstract}
Due to ever increasing extremities of disasters and accidents, rescue operations have become more and more complicated, requiring both theoretically and practically better qualified rescue personnel. It is a serious problem that methods of using special rescue equipment, rely in many cases only on oral-based communication, while the offer of new equipment's developed by manufacturers is growing dynamically. Such a change in the rescue equipment can also be observed in the case of rescue work with rope rescue technique where the safe use of equipment is vital.

The purpose of the study, based on mathematical statistical processing of the results of a specially designed questionnaire research, is to answer the question how the users evaluate to the usage safety of three selected rope technological devices. An additional purpose was, based on these results, to make suggestions on improving usage safety concerning these devices.

In my first part of my study, I analyze the results of the Mann-Whitney test and Spearman's correlation.
\end{abstract}

Keywords: Rope technique, Rescue equipment, Statistics, Safety, Spearman's correlation

A kézirat benyújtásának dátuma (Date of thesubmission): 2019.02.13.

A kézirat elfogadásának dátuma (Date of theacceptance): 2019.03.12. 


\section{BEVEZETÉS}

A ma már szinte mindennapossá vált mentések mellett, egyre nagyobb igény van a különleges mentést végzök speciális felkészítésére, professzionális eszközparkjuk megfelelö felszerelésére. A balesetek extrémitása miatt a mentési müveletek egyre összetettebbé váltak, ez pedig mind elméleti, mind pedig gyakorlati szempontból felkészültebb mentési szakszemélyzetet kíván meg.

A hivatásos katasztrófavédelmi erők, felismerve az összetett balesetek és a dinamikusan változó veszélyeztetettségből kialakuló komplex veszélyhelyzetek növekvő kockázatát, a tüzoltás és a müszaki mentés mellett - egyebek között - már jelenleg is alkalmazzák az alpin, azaz a kötéltechnikai technikai mentést a magasból és a mélyből történő mentés eseteiben [1]. Ilyenek például a búvármentés sebes folyású folyókban, rosszlátási viszonyú tavakban, vagy a jégről történő mentés. Komoly problémát jelent, hogy a különleges mentéseknél alkalmazott eszközök használatának módszerei és a mentések tényleges lebonyolításának a módja sok esetben csupán „szájhagyományon" alapuló közlésekre támaszkodik.

Az életmentésnél fontos, hogy a mentést végzök elméleti és gyakorlati tudása, egészségügyi és mentális felkészültsége biztos legyen, még akkor is, ha a mentési helyzetek és körülmények nem ideálisak, vagy az eddig megtanult és begyakorolt módszerektől eltérő megoldást kívánnának.

A speciálisan kiképzett és különlegesen felszerelt, mentésbe bevonható önkéntes mentőszervezetekben tevékenykedő szakemberek készen állnak az emberi élet-, egészség és az anyagi javak mentésére [2]. Ugyanakkor szükséges, hogy számukra olyan müszaki, oktatástechnikai, pedagógiai, pszichológiai módszereket kínáljunk, amelyek garantálják a biztonságos és balesetmentes munkavégzést, illetve mentést, javítva a bajbajutott embertársaink túlélési esélyeit [3].

\section{KUTATÁSI CÉLOK ÉS KÉRDÉSEK}

Biztonságtudományi doktori iskolai kutatás keretében vizsgáltam három kiválasztott konkrét kötéltechnikai eszköz felhasználóinak a véleményét ezen eszközök biztonságos használhatóságáról, valamint alkalmazási és döntési szokásait a felszerelések kiválasztása és használata oldaláról. A mentési szakterületek közül ez a legelterjedtebb, amely használóitól alapos felkészültséget kíván meg, miközben egyébként is széles eszközparkja dinamikusan továbbfejlődik. Ezen felszerelések használatával kapcsolatban különböző módszerek, gyártói utasítások és hagyományok terjedtek el, így a terület vizsgálata hiánypótlónak ígérkezett. Másfelől azonban a kötéltechnikával foglalkozó, igen különböző élet- és szakmai tapasztalattal rendelkező, civil és hivatásos felhasználók által ténylegesen alkalmazott eszközhasználati gyakorlat felmérése jelentős módszertani kihívást jelentett.

A téma kutatása érdekében korábbi tapasztalataimra támaszkodva egy 52 kérdéses kérdőivet készítettem (1. függelék), amelyet a kötéltechnikai mentéssel, hegymászással, ipari alpintechnikával, barlangi mentéssel és barlangászással foglalkozó szakembereknek, sportolóknak, hivatásos tűzoltóknak és kedvtelési céllal kötéltechnikai eszközöket használó civileknek szántam. Három konkrét kötéltechnikai eszköz vizsgálatát céloztam meg, amelyböl kettő speciális, de a különböző gyártók által kifejlesztett, összetett mechanikai működésü, modern, magasabb árfekvésü eszköz a mászógép és az ereszkedögép. A harmadik egy hagyományos, más eszközzel legtöbbször együtt használatos felszerelés, a karabiner, amelyet a gyártók a zárszerkezet és anyagösszetétel tekintetében fejlesztettek tovább. Mindhárom eszköz ma már nagyon népszerü és közkedvelt a felhasználók körében. A tematikus, mintegy 10 perc alatt kitölthető kérdőív elsősorban a három felszerelés biztonságos használhatóságáról, illetve a kiválasztás szempontjairól kérdezte a válaszadót. 
A kérdőíves kutatás célja az volt, hogy alkalmas matematikai statisztika módszerek segítségével egy lehetőség szerint árnyalt képet kapjunk a kötéltechnikai eszközök biztonságos használhatóságával és konkrét használati módjaival kapcsolatos véleményekről és gyakorlatokról a professzionális és a sportcélú felhasználók körében. A kutatás különösen arra kereste a választ, hogy a katasztrófavédelem rendszerében a kötéltechnikai mentések kockázatait hogyan tudjuk csökkenteni, elkerülve a beavatkozók vagy a mentendő személyek mentés során bekövetkezett sérülését, visszaszorítva az ilyen másodlagos balesetek előfordulásának kockázatát. Az összesített eredmények ismeretében célom, javító intézkedések, javaslatok megfogalmazása a gyártók és a felhasználók felé.

A kutatás alapkérdései:

1. A válaszok statisztika elemzésével mutatható-e ki a kötéltechnikai eszközök használatával kapcsolatos biztonságot növelő szakmai tényező? Tudunk-e új szakmai ajánlásokat megfogalmazni a gyártók és a felhasználók részére?

2. Az újszerü és a hagyományos felszerelések használatával kapcsolatos válaszokból megfogalmazhatók-e előremutató következtetések a biztonságos felhasználásra?

3. A biztonság szempontja mennyire érvényesül a felhasználók körében a kötéltechnikai eszközök kiválasztása és alkalmazása során?

Az 52 kérdés angol és magyar nyelven készült el és Internetes kérdőív formájában (1. ábra), valamint egy professzionális közösségi oldalon lett közzé téve. A szakmai felhasználók közvetlen elérése érdekében több nagyobb magyar technikai ernyöszervezet is megkapta a kérdőívet. A kérdőívet kitöltötte a Magyar Barlangi Mentőszolgálat, amely a nemzetközi partnereinek is eljuttatta, valamint a Magyar Ipari Alpintechnikát Oktatók Érdekvédelmi Egyesülete, amely a tagok részére kiajánlotta a kérdőívet. A kérdőívet a mentéssel foglalkozó szervezetek közül Magyarország hivatásos, központi mentőszervezete, a HUNOR kötéltechnikai-mentési egység tagjai és a Katasztrófavédelmi Oktatási Központ szakoktatói is kitöltötték.
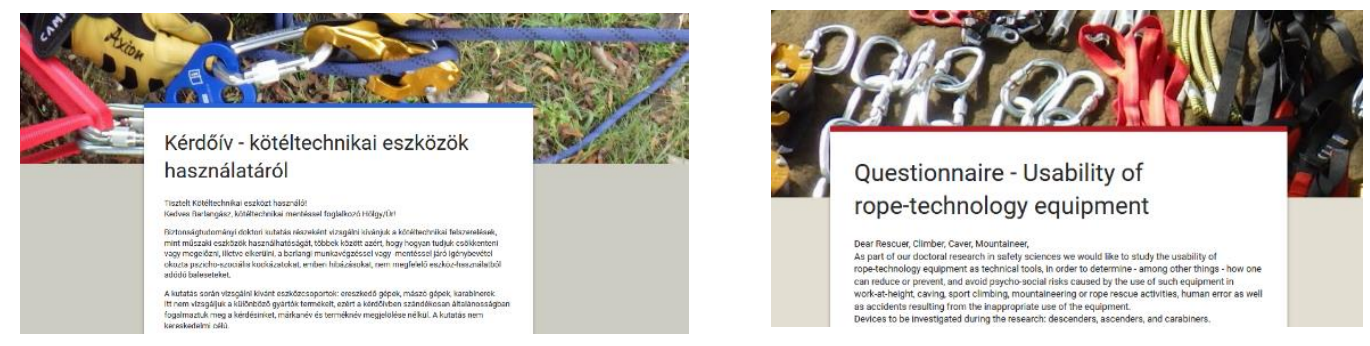

1. ábra Internetes kérdőív magyar és angol változatának induló oldala (Saját szerkesztés. Szoftver: Google Drive)

\section{AZ ALKALMAZOTT STATISZTIKAI MÓDSZEREK ÉS AZ EREDMÉNYEK}

Összességében 314 fö tekintette meg az angol vagy a magyar nyelvű kérdőíveket és ebből 24 fő szánta rá magát a kitöltésre. A kérdöív eszközcsoportonként, lépésről lépésre engedte elöre a válaszadókat a kitöltésben. A válaszadóknak 1 (leginkább nem ért egyet) és 5 (leginkább egyet ért) közötti skálán kellett megadniuk a kérdésekre a válaszokat. Arra a kérdésre, amelyre a kitöltő nem tudott vagy nem akart választ adni 0 (nem tudom megítélni) értéket adhatott, ilyen válaszok csupán egy-két kérdés esetén, és csupán néhány válaszadónál fordultak elő. A kérdéseket, tehát formálisan egy hatfokú skálán kellett értékelnie a válaszadónak, de mivel a 0 válaszok a „nem tudom megítélni” esetet jelentették, valójában csak az 1, 2, 3, 4 és 5 értékek képeztek statisztikailag feldolgozható ordinális skálát.

A kérdésekre adott válaszok jobb értelmezhetősége érdekében, szakmai tapasztalat alapján két kitöltői csoportot hoztam létre. Az 1-10 év szakmai tapasztalattal rendelkezők a ,junior”, a 
11-30 év pedig a „,senior” kategória-jelzőt kapták. A kérdőív feldolgozása első lépésben, ebben a két kategóriában adott válaszok összehasonlításával kezdődött.

A tanulmány első részében a kérdőívvel kapott nyersadatokat az alábbi módszerekkel vizsgáltam, illetve értékeltem ki:

1. Mann-Whitney próba a két független minta összehasonlítására;

2. Spearman-féle rangkorreláció a kapcsolatok vizsgálatára;

3. Leíró statisztikák.

Közismert, hogy a vizsgálni kívánt terület nagyon specifikus, itthon és külföldön csak néhány szakértő müveli, így tekintettel arra, hogy a 24 kitöltött kérdőívvel nyert adatok csupán mérsékelten tekinthetők reprezentatívnak, így a megalapozottabb következtetések meghozatalára, a fenti problémát később egy másik módszerrel is megvizsgálom. Ezt a tanulmány második részében az ún. Q-módszertan segítségével végeztem el, amelyhez nem szükséges feltétlenül nagy létszámú válaszadót bevonni. A Q-módszertan segítségével elvégzett elemzésbe 7 gondosan kiválasztott szakértőt vontam be, olyanokat, akik aktívan részt vesznek az ipari vagy a sport célú alpintechnikai tevékenységben, ismerik a régi vagy az új felszereléseket, kezdőként vagy oktató szintü szakértőként müködnek közre, tagjai a HUNOR Mentőszervezetnek, így alkalmazzák a kötéltechnikai mentést és 5-25 év közötti szakmai tapasztalattal, illetve gyakorlati idővel rendelkeznek. A kiválasztott személyek probléma vizsgálhatósága szempontjából így „reprezentativ módon” lettek kiválasztva

$\mathrm{Az}$ alkalmazott statisztikai programcsomag az IBM SPSS Statistics 23 verziója volt, amelynek használatára a jogot, a Budapesti Müszaki és Gazdaságtudományi Egyetem Ergonómia és Pszichológia Tanszékétől kaptam meg.

\section{A két független minta összehasonlítása Mann-Whitney próbával}

A kérdőív feldolgozását a megfelelő statisztikai próba kiválasztásával kezdjük [4]. A szakmai tapasztalat alapján két független csoportot (Junior és Senior korcsoportot) tudtunk létrehozni. Tekintettel arra, hogy a kérdőívből ordinális mérési szintü adatokat kaptam, a két csoport összehasonlítására ezért már eleve csak a nemparaméteres Mann-Whitney próbát alkalmaztam. Itt a nullhipotézisem az volt, hogy nincs különbség a két válaszadó csoport) között.

A kutatási kérdés tehát az volt, hogy különbözik-e szignifikánsan a két csoport az egyes változók (az 52 kérdésre adott válaszok) vonatkozásában. A Mann-Whitney próba eredményei azt mutatták, hogy a kötéltechnikai felszerelések használatára vonatkozó 52 kérdésre adott válaszok egyikében sincs eltérés a junior és a senior válaszadók között. A továbbiakban ezért nincs értelme a tapasztaltabb válaszadók értékelését nagyobb súllyal figyelembe venni [5]. Tapasztalat az, hogy szakmai döntéseknél az idősebb munkatársak véleményét veszik figyelembe. A felmérés viszont nem erősítette meg azt, hogy a junior és a senior válaszadók között kellene különbséget tenni. A senior válaszolók értékelésében kisebb a szórás, azaz egységesebb véleményen voltak, szélsőséges vélemények nem fordultak elő.

\section{AZ EREDMÉNYEK ÉRTÉKELÉSE}

Tekintettel arra, hogy a válaszadók értékelésében szakmai tapasztalat és kötéltechnikai eszközcsoport tekintetében nincs eltérés, ezért az eszközcsoportok azonos kérdéseit 4 féle szempont alapján összevontam, az alábbiak szerint:

1. Felszerelés biztonságos használata;

2. Felszerelés kezelhetősége;

3. Gyártói elöírás, felhasználói utasítás;

4. Design (kialakítás), termék bolti ára. 
Az 52 kérdést eszközcsoportonként a fenti 4 szempont szerint csoportosítottam. A biztonsággal foglalkozó 6 kérdést a „Biztonság” kategóriába, a kezelhetőséggel, munkavégzéssel, használhatósággal foglalkozó 8 kérdést a „Kezelhetőség” kategóriába, a gyártói javaslattal, elöírással foglalkozó 3 kérdést a „Gyártói elöírás” kategóriába és az esztétikával, költséggel, kialakítással foglalkozó 4 kérdést a „Design és termék ára” kategóriába osztottam be mind a három felszerelés esetében. A mászógép tekintetében a 22 . kérdés, mint plusz kérdés a „Kezelhetőség” kategóriába került, a karabiner használatra vonatkozó kilenc kérdés pedig arányos módon lett felosztva az új kategóriákban.

A kérdések összevonását az 1. táblázat tartalmazza. Az összevonás egyszerü átlagolással történt. Az adott kérdéseket az SPSS kódok szerint az 1. függelék tartalmazza.

\begin{tabular}{|l|l|l|}
\hline Termékcsoport & \multicolumn{1}{|c|}{ Négy kategória } & \multicolumn{1}{|c|}{ Kérdések csoportositása az SPSS kódok alapján } \\
\hline \multirow{4}{*}{ Ereszkedőgép } & Biztonság & Desc02, Desc04, Desc11, Desc12, Desc18, Desc21 \\
\cline { 2 - 3 } & Kezelhetöség & Desc03, Desc08, Desc10, Desc13, Desc15, Desc17, Desc19, Desc20 \\
\cline { 2 - 3 } & Gyártói elöírás & Desc16, Desc14, Desc09 \\
\cline { 2 - 3 } & Design, termék ára & Desc07, Desc06, Desc05, Desc01 \\
\hline Mászógép & Biztonság & Asc02, Asc04, Asc11, Asc12, Asc18, Asc21 \\
\cline { 2 - 3 } & Kezelhetőség & Asc22, Asc03, Asc08, Asc10, Asc13, Asc15, Asc17, Asc19, Asc20 \\
\cline { 2 - 3 } & Gyártói elóírás & Asc09, Asc14, Asc16 \\
\cline { 2 - 3 } & Design, termék ára & Asc01, Ascv05, Asc06, Asc07 \\
\hline Karabiner & Biztonság & Cara01, Cara03 \\
\cline { 2 - 3 } & Kezelhetőség & Cara04, Cara05, Cara06, Cara07 \\
\cline { 2 - 3 } & Gyártói elöŕrás & Cara02 \\
\cline { 2 - 3 } & Design, termék ára & Cara08, Cara09 \\
\hline
\end{tabular}

1. táblázat Az ereszkedőgép, a mászógép és a karabiner használhatóságának elemzésére az 52 eredeti változó helyett bevezetett négy új kategória (változó) és az ezekhez tartozó eredeti kérdések SPSS kódjai (Desc, Descender=Ereszkedőgép; Asc, Ascender=Ereszkedőgép; Cara, Carabiner=Karabiner; a szerző szerkesztése).

\section{Spearman-féle rangkorrelációs vizsgálat az új bevezetett változókkal}

A Spearman rangkorrelációs vizsgálat célja annak megvizsgálása volt, hogy az 1. táblázatban szereplö egyes változók egymással milyen mértékben függenek össze. Ismeretes, hogy a Spearman-féle rangkorrelációs együttható két rangsor közötti egyezés egy nemparaméteres mérőszáma. [5][6][6]. Hipotézis: Van-e együtt járás az eszközcsoportok kiválasztási szempontjainak fontossága között? Például: Mászógép-Ereszkedögép esetében a gyártó vagy a szín befolyásoló tényezö?

\section{A mászógép használatának elemzése}

A mászógép esetében a válaszadók a használat és felszerelés választása során a biztonságot, a felszerelés kezelhetôségét és a gyártói elöírást részesítik előnyben. Választásukat nem befolyásolja a mászógép színe, designja vagy a bolti ára. A válaszadók szerint a mászógép esetében a biztonsági, a kezelhetőségi tényezőknek és a gyártói javaslatoknak együttesen kell érvényesülnie az eszközök használata során (2. táblázat). 
JACKOVICS: A Különleges mentési felszerelések biztonságos használatának elemzése statisztikai...

\begin{tabular}{|c|c|c|c|c|c|c|}
\hline \multicolumn{7}{|c|}{ Correlations } \\
\hline & & & Biztonsag_Mg & Kezelhetoseg_Mg & Gyartoi_eloiras_Mg & $\begin{array}{c}\text { Design_TermekAra } \\
\text { _Mg }\end{array}$ \\
\hline \multirow[t]{12}{*}{$\begin{array}{l}\text { Spearman's } \\
\text { rho }\end{array}$} & \multirow[t]{3}{*}{ Biztonsag_Mg } & $\begin{array}{l}\text { Correlation } \\
\text { Coefficient }\end{array}$ & 1,000 &, $599^{* *}$ &, $597^{* *}$ & ,177 \\
\hline & & Sig. (2-tailed) & & ,002 & ,002 & ,407 \\
\hline & & $\mathrm{N}$ & 24 & 24 & 24 & 24 \\
\hline & \multirow[t]{3}{*}{$\begin{array}{l}\text { Kezelhetoseg_ } \\
\mathrm{Mg}\end{array}$} & $\begin{array}{l}\text { Correlation } \\
\text { Coefficient }\end{array}$ &, $599^{* *}$ & 1,000 &, $568^{* *}$ &,- 011 \\
\hline & & Sig. (2-tailed) & ,002 & & ,004 & ,960 \\
\hline & & $\mathrm{N}$ & 24 & 24 & 24 & 24 \\
\hline & \multirow[t]{3}{*}{$\begin{array}{l}\text { Gyartoi_eloiras_ } \\
\text { Mg }\end{array}$} & $\begin{array}{l}\text { Correlation } \\
\text { Coefficient }\end{array}$ &, $597^{* *}$ &, $568^{* *}$ & 1,000 & 136 \\
\hline & & Sig. (2-tailed) & ,002 & ,004 & & ,528 \\
\hline & & $\mathrm{N}$ & 24 & 24 & 24 & 24 \\
\hline & \multirow[t]{3}{*}{$\begin{array}{l}\text { Design_Termek } \\
\text { Ara_Mg }\end{array}$} & $\begin{array}{l}\text { Correlation } \\
\text { Coefficient }\end{array}$ & , 177 &,- 011 & ,136 & 1,000 \\
\hline & & Sig. (2-tailed) & 407 & ,960 & ,528 & \\
\hline & & $\mathrm{N}$ & 24 & 24 & 24 & 24 \\
\hline
\end{tabular}

2. táblázat A mászógép használatának Spearman rangkorrelációs vizsgálattal végzett elemzésének eredményei. A szignifikáns korrelációs együtthatókat sárgával jelöltük (sárga: $\operatorname{sig} \leq 0.01$ ). Mg=mászógép (Szoftver: SPSS. Saját elemzés alapján)

A mászógép esetében a karbantarthatóságot és más, meglévő felszereléssel történő együttes használhatóságot, a kompatibilitást tartják fontosnak a válaszadók. A karbantarthatóság mellett fontos szempont a mászógépre vonatkozó gyártói javaslat, gyártói garancia, valamint biztonsági oldalról az, hogy piszkos-sáros körülmények között és önbiztosítással tudják az eszközt használni [9]. A karbantarthatóság esetében fokozottan figyelembe veszik a válaszadók a gyártói javaslatot, elöírást és a garanciát, továbbá fontos biztonsági szempont az, hogy a mászógép más termékkel együtthasználható, kompatibilis legyen. A válaszadók számára kiemelten fontos a kompatibilitásra adott gyártói javaslat, hiszen a felszerelést önbiztosításra is használják a felhasználók.

A mászógép esetében a válaszadók használat és felszerelés választás során a biztonságot, a felszerelés kezelhetőségét és a gyártói elóírást részesítik előnyben. Választásukat nem befolyásolja a mászógép színe, designja vagy a bolti ára. A válaszadók szerint a mászógép esetében a biztonsági, a kezelhetőségi tényezőknek és a gyártói javaslatoknak együttesen kell érvényesülnie az eszközök használata során. Az eredmények ismeretében elemezzük a kapott eredmények korösszetételét ismét Mann-Whitney próbával [8], akkor láthatjuk, hogy a mászógép kezelhetősége a senior felhasználók számára fontosabb és lényegesebb szempont (2. ábra $)^{1}$.

\footnotetext{
${ }^{1}$ A tanulmány készítésénél a szignifikánsan korrelált változókat igyekeztem elemezni, ezért a mászógép esetében nem vizsgáltam a „,design és termék ár” változóra adott korcsoporti válaszokat.
} 


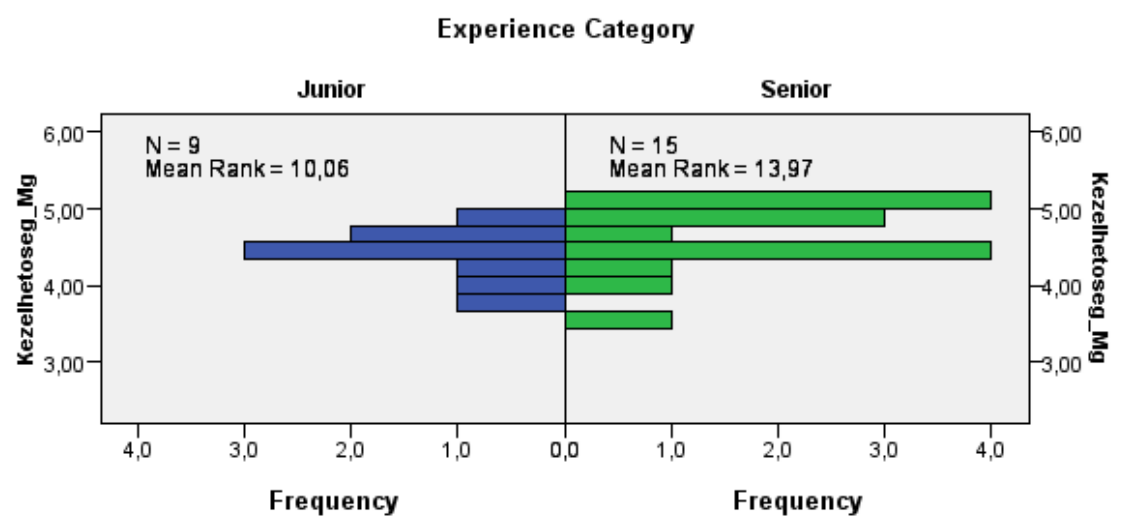

2. ábra A mászógép kezelhetőségére adott válaszok korcsoporti (tapasztalat, experience) bontásban. U=89,5 p=0.186 (Szoftver: SPSS. Mg=Mászógép, Saját feldolgozás alapján)

Mászógép esetében a válaszadóknál a biztonság és a gyártói előírás erősen érvényesül, valamint a kezelhetőség is számít.

- Az a válaszadó, aki a mászógép tekintetében a biztonságot teszi az első helyre, az az ereszkedőgépnél is a biztonságot figyeli, együtt a kezelhetőséggel. Karabiner esetében is a biztonság kategória dominál.

- A mászógép kezelhetőségét első helyre tevőknél, az ereszkedőgép választásánál is a kezelhetőség számított. Minkét eszköznél az a müszaki megoldás érdekli a felhasználókat, amelyek kézzel könnyen kezelhetőek és kötéllel könnyen alkalmazásba helyezhetőek.

- Senior válaszadóknál a kezelhetőség fontosabb, átlagban magasabb értékelést kapott.

- Összességében a biztonság (1), a gyártói előírás (2) és a kezelhetőség (3) mentén választanak a felhasználók mászógépet.

\section{Ereszkedőgép használatának elemzése}

Az ereszkedőgépek használata esetében a gyártói garancia mellett fontos az eszköz teherbírása, karbantarthatósága és a bolti ára. A használók biztonsági szempontból az eszköz terhelhetőségét, teherbírását tartják az egyik legfontosabb választási tényezőnek. A válaszadóknál a felszerelés márkája másodlagos választási tényező. Összehasonlításképpen megfigyelhető, hogy a válaszadók a mászógépre és az ereszkedőgépre más-más súllyal adtak véleményt, tekintettel arra, hogy a mászógép a gyakorlatban többfunkciós eszközként is használatos, így akár egykezes vagy kétkezes mászásra, vagy mentéshez [9]. 
JACKOVICS: A Különleges mentési felszerelések biztonságos használatának elemzése statisztikai...

\begin{tabular}{|c|c|c|c|c|c|c|}
\hline \multicolumn{7}{|c|}{ Correlations } \\
\hline & & & Biztonsag & Kezelhetoseg & Gyartoi_eloiras & Design_TermekAra \\
\hline \multirow[t]{12}{*}{$\begin{array}{l}\text { Spearman's } \\
\text { rho }\end{array}$} & \multirow[t]{3}{*}{ Biztonsag } & \begin{tabular}{|l} 
Correlation \\
Coefficient
\end{tabular} & 1,000 &, $423^{\circ}$ & ,346 & , \\
\hline & & Sig. (2-tailed) & & ,039 & ,097 & ,008 \\
\hline & & $\mathrm{N}$ & 24 & 24 & 24 & 24 \\
\hline & \multirow[t]{3}{*}{ Kezelhetoseg } & $\begin{array}{l}\text { Correlation } \\
\text { Coefficient }\end{array}$ &, $423^{\circ}$ & 1,000 & ,594" & 274 \\
\hline & & Sig. (2-tailed) & ,039 & & ,002 & 195 \\
\hline & & $\mathrm{N}$ & 24 & 24 & 24 & 24 \\
\hline & \multirow[t]{3}{*}{ Gyartoi_eloiras } & $\begin{array}{l}\text { Correlation } \\
\text { Coefficient }\end{array}$ & ,346 & ,594" & 1,000 & 287 \\
\hline & & Sig. (2-tailed) & ,097 & ,002 & & 175 \\
\hline & & $N$ & 24 & 24 & 24 & 24 \\
\hline & \multirow[t]{3}{*}{$\begin{array}{l}\text { Design_Termek } \\
\text { Ara }\end{array}$} & $\begin{array}{l}\text { Correlation } \\
\text { Coefficient }\end{array}$ & ,526" & ,274 & 287 & 1,000 \\
\hline & & Sig. (2-tailed) & ,008 & 195 & , 175 & \\
\hline & & $\mathrm{N}$ & 24 & 24 & 24 & 24 \\
\hline
\end{tabular}

1. táblázat Ereszkedőgép használatának Spearman korrelációs vizsgálattal végzett elemzése a szignifikánsan korrelált összegzett eredményekkel, jelölve (sárga: $s i g \leq 0.01$; zöld: sig $\leq 0.05$ ) ahol a korreláció szignifikáns. (Szoftver: SPSS. Saját elemzés alapján)

Ereszkedőgép esetében a biztonságot összekapcsolják a termék designjával és a bolti árával, a gyártói előírást a kezelhetőséggel. Ereszkedőgép esetén a biztonságnak és a kezelhetőségnek együttesen kell érvényesülnie.

Ereszkedőgép esetében a válaszadóknál a kezelhetőség fontos tényező, válaszadásban az eszközök közül azokat használják, amely használata üzembiztosabb és könnyebben helyezhetö alkalmazásba, füzhető be a kötélzetbe, kézzel való kezelése egyszerübb. Az alábbi összegzett eredmények születtek:

- Az a válaszadó, aki az ereszkedőgép tekintetében a kezelhetőséget teszi első helyre, annál mászógép biztonsága, kezelhetősége, gyártói előírása is fontos.

- Ereszkedőgép biztonságos használata szintén együttállást mutat a karabiner a biztonságos használatával. Itt valójában a két eszköz együtthasználata, kompatibilitása kap hangsúlyt.

- Összességében a kezelhetőség (1) és a biztonság (2) mentén választanak a felhasználók [10][11] (3. ábra).

\section{Experience Category}

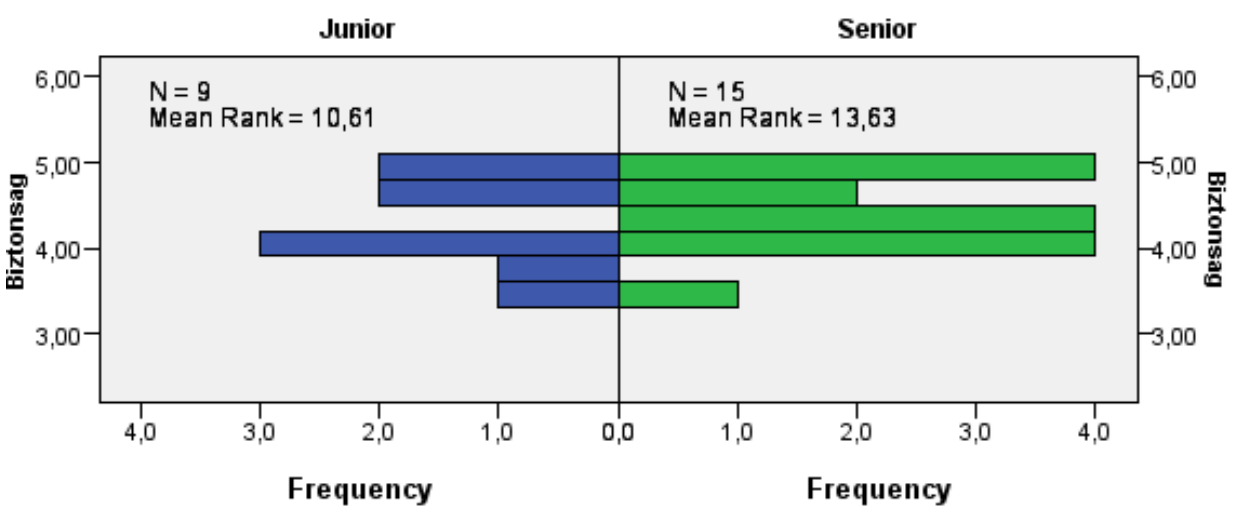

3. ábra Az ereszkedőgép biztonságos használatára adott válaszok korcsoporti (tapasztalat, experience) bontásban U=84,5 p=0.307 (Szoftver: SPSS. Saját feldolgozás alapján) 


\section{Karabiner használatának elemzése}

Karabinerek tekintetében a válaszadók a karabiner más felszereléssel történő együtthasználatát veszik figyelembe a felszerelés választásánál. Döntésükben az elmúlt időszakban, a felszerelés használatával szerzett korábbi tapasztalat dominál. Ez a válasz jól mutatja azt, hogy a karabinert általában más felszereléssel együtt használják, így a mászógéppel vagy ereszkedőgéppel együtt (4. ábra).

\begin{tabular}{|c|c|c|}
\hline $\begin{array}{c}\text { Szignifikánsan korreláló két } \\
\text { kérdés }\end{array}$ & $\begin{array}{c}\text { Döntését mennyire befolyásolja: A } \\
\text { karabiner más felszereléssel történő együtt } \\
\text { használata? }\end{array}$ & $\begin{array}{c}\text { Döntését mennyire befolyásolja: A } \\
\text { karabiner használat során szerzett } \\
\text { korábbi tapasztalat? }\end{array}$ \\
\hline
\end{tabular}

4. ábra: Karabiner használatának Spearman korrelációs vizsgálattal végzett elemzés eredménye. Felszerelés használat és korábbi tapasztalat összefügg (SPSS elemzés összegzett kivonatolt eredménye, saját szerkesztés).

A junior felhasználók számára a karabiner külső megjelenése, tervezése és ára erősebben érvényesül. A senior felhasználók számára nem elsősorban ez jelent fontos tényezőt [12], [13] (5. ábra) ${ }^{2}$.

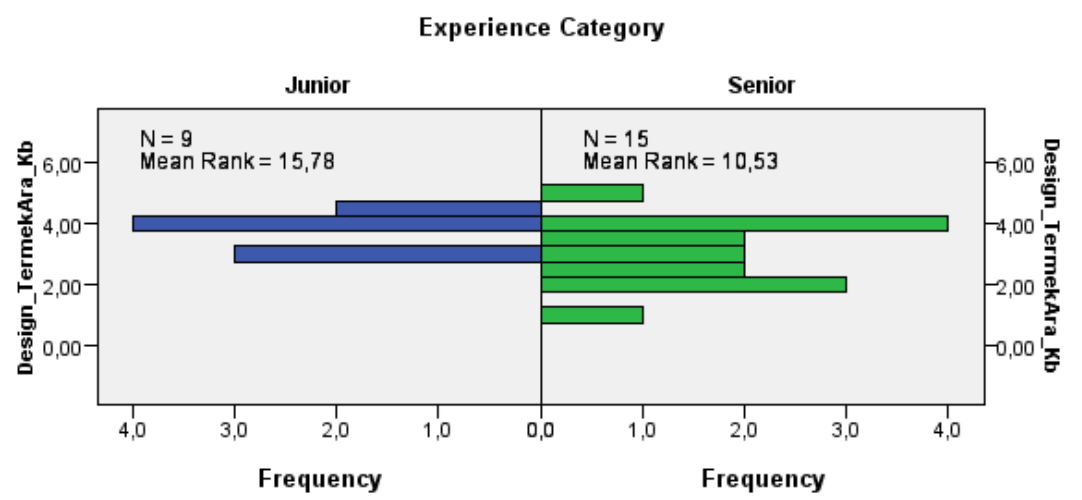

5. ábra A karabiner „termék kialakítása, bolti ára” kérdésre adott válaszok korcsoporti (tapasztalat, experience) bontásban U=49,0 p=0.261 (Szoftver: SPSS. Saját feldolgozás alapján)

\section{KÖVETKEZTETÉSEK}

Az 52 kérdéssel és a válaszadók un. egyenszilárd véleményalkotásával sikerült egy újszerü módszerrel felmérni a kötéltechnikai eszközök biztonságos használatát a kötéltechnikával foglalkozó civil és professzionális felhasználók között. Az alacsony elemszámot az is magyarázza, hogy nagyon speciális területről van szó és ezért kevesen vállalkoztak érdemi válaszadásra. Természetesen az is lehetséges, hogy többeket a nagy kérdésszám riasztott vissza a kérdőív kitöltésétől, illetve külföldiek esetében az angol nyelv használata. A kötéltechnikai eszközök használhatóság oldaláról történő felmérése jó alapot szolgáltat a biztonságtudományi kérdések, így a kezelhetőség, a biztonságos használat, a gyártói előírás vagy a termék kialakítása szempontjainak a mérésére. Ebben, megítélésünk szerint Magyarországon úttörő lépést sikerült tenni, hiszen a hazai szakmai ernyőszervezetek támogatták a felmérést.

A potenciális válaszolók direkt módon történő megkeresésével valószínű növelhető lett volna a kitöltők száma, de ez az öncélú módszer, marketing alapú megközelítés, nem a tudományos kutatás célja. A kutatás során szándékosan általánosságban fogalmaztam meg az

\footnotetext{
2 A tanulmány terjedelmi korlátja miatt a mintaként szolgáló, egyes termékcsoportra vonatkozó korcsoporti válaszokat publikálom. A két korcsoport között a mászógép esetében csak a „,kezelhetőségre”, az ereszkedőgép esetében csak a „biztonságos használatra”, a karabiner esetében csak a „termék kialakítása, bolti ára” változóra végeztem el az összehasonlítást.
} 
eszközcsoportok elnevezését, olyan gyüjtőfogalmat használva, amely tudatosan nem utal gyártói termékre, konkrét típusra [14].

A karabiner, a mászógép és az ereszkedőgép kérdéseit újracsoportosítva, mérhetőbb és gyakorlatiasabb válaszokat kaptam akár a termék kiválasztásának együttállásairól vagy a felhasználók felszereléssel szembeni elvárásairól. A 4 szempont szerinti újracsoportosítás segítette az 52 kérdésre adott válasz konkrétabb értelmezését.

Figyelemre méltó, hogy a karabiner választásánál a senior válaszolók nem a biztonságot részesítik elönyben, viszont a hagyományos kötéltechnikai eszköz ellenére, a junior válaszolóknak nagy elvárásai vannak a karabinerrel szemben, mert magasabban értékelték a válaszaikat. A junior válaszolók a mászógép és az ereszkedőgép tekintetében gyengébbnek értékelik a termékre vonatkozó gyártói utasítást, használati elöírásokat.

A leíró statisztika eredményeiből látszik, hogy helyes szakmai döntés volt újracsoportosítani a beérkezett kérdésekre adott válaszokat, ezzel az elérendő célra tudtunk összpontosítani. A biztonságtudomány és az alkalmazott matematikai statisztikai módszerekkel új eredmények születtek.

\section{Válaszok a kutatási kérdésekre}

A tanulmány készítésével egy időben, a HUNOR Mentőszervezet állománya tesztelte a kérdőívre adott válaszok eredményeit, fokuszálva a biztonságos eszközhasználatra. Az elméletigényes gyakorlat eredményét jelen publikáció fényképei mutatják be. A szakértői állomány átbeszélte a kapott teoretikus eredményeket, amelyek gyakorlati absztrahálásával jutottunk az alábbi következtetésekre.

1) Kutatás elején feltett kérdés: A válaszok statisztika elemzésével mutatható-e ki a kötéltechnikai eszközök használatával kapcsolatos biztonságot növelö szakmai tényezö? Tudunk-e új szakmai ajánlásokat megfogalmazni a gyártók és a felhasználók részére? Válaszok:

a) A junior és a senior csoportok oldaláról történő probléma-feldolgozás, azaz a szakmai tapasztalat szerinti kötéltechnikai eszközök használhatóságának felmérése rámutatott arra, hogy fontos a biztonság kérdése.

b) A müszakilag bonyolultnak tünő, összetett müködésű mászógépek és ereszkedőgépek oktatásánál, az eszközhasználat jártásságát fokozó, elmélet igényes gyakorlat óraszámát tudatosan növelni kell [15].

c) Ereszkedőgép és mászógép tekintetében a karabinerrel és kötéllel történő együtthasználatot gyakorolni kell, javasolt lenne részletesebb, „lépésröl lépésre" vonatkozó, képpel kiegészített gyártói leírás kiadása (6. ábra).

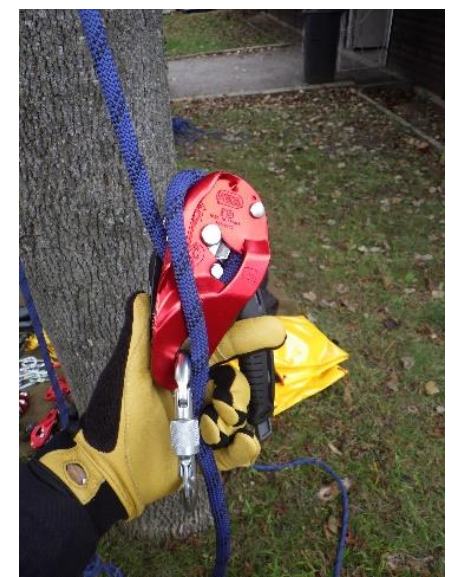

6. ábra Ereszkedőgép elökészítése a befüzött kötéllel és karabinerrel történő együtthasználatra, a felhasználó által a kötél irányba tartására. Ilyen ábrák segíthetik a biztonságos eszközhasználat megértetését (Fotó: HUNOR Mentőszervezet) 
2) Kutatás elején feltett kérdés: Újszerü és hagyományos felszerelések használatával kapcsolatos felmérés elöremutató következtetéseket ad-e a biztonságos felhasználásra? Válasz: mind az újszerü (mászógép, ereszkedőgép) és a hagyományos (karabiner) kötéltechnikai felszerelés igen elterjedtek.

a) A felhasználók kötéltechnikai eszközcsoportok kiválasztását mindig a technikailag bonyolultabb eszköz kiválasztásával kezdik: mászógép, ereszkedőgép. A karabiner, mint kiegészítő, támogató eszköz a kiválasztása csak ezt követően történik meg [16].

b) Karabiner kiválasztása a mászógép vagy az ereszkedőgép együtthasználhatóságának (kompatibilitás) ismeretében történik meg.

c) Mindhárom felszerelésnél a használat utáni és rendszeres karbantarthatóságra vonatkozó gyártói utasítást rendszeresíteni kell. A karbantartásra, eszközellenőrzésre vonatkozó előírásokat „laikus” felhasználó számára is, a gyártónak ki kell dolgoznia.

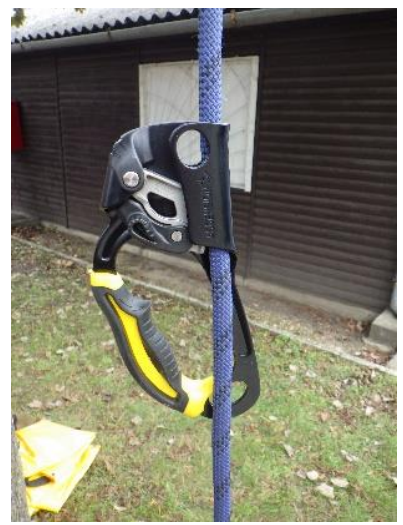

7. ábra Mászógép kötéllel történő együtthasználata. Ilyen magyarázó ábra segítheti a kezdő felhasználót az biztonságos eszközhasználatban (Fotó: HUNOR Mentőszervezet)

3) Feltett kérdés: Felhasználók körében, a kötéltechnikai eszközök választásánál a biztonság kérdése mennyire érvényesül? Válasz: a kötéltechnikai felszerelések biztonságos használatra vonatkozó kérdések fontosságára magas értékelési pontokat adtak a válaszadók, viszont felszerelésenként eltérő súlyozással.

a) A gyártók számára fontos lenne, hogy azonos gyártótól piacon kapható termékek együtthasználatára eljárásrendet dolgozzanak ki. Törekedni kell arra, hogy nemcsak az adott termékre legyen felhasználói útmutató, hanem az adott termék más termékkel történő együtthasználatára is [17].

b) Az mászógép-ereszkedőgép-karabiner rendszerben a kompatibilitásra vonatkozó leírást szükséges kidolgozni. A gyártók a felhasználóval legtöbbször csak a rendszer müködési sémáját közlik, azt nem, hogy a saját termékei közül melyik konkrét karabinert vagy mászógép, ereszkedőgép típust használja a felhasználó (7. ábra).

c) A mászógép és ereszkedőgép esetében, az a müszaki megoldás érdekli a felhasználókat, amelyek kézzel könnyen kezelhetőek és kötéllel könnyen alkalmazásba helyezhetőek. A felszerelések kötéllel való összefüzését sematikus ábrán a gyártónak célszerü ismertetni, ahogy a HUNOR Mentőszervezet felkészítésén tesztelhettem (8. ábra).

\begin{tabular}{|c|c|c|}
\hline Nyújtott biztonság & Felszerelés kezelhetősége & Gyártói elöírás \\
\hline Munkavédelem & Egyéni teljesítmény & Garancia hossza \\
\hline Hatékonyság & Kényelmes használat & Gyártói garancia megléte \\
\hline Védelmi képesség & Alkalmazhatóság & Gyártói javaslat \\
\hline
\end{tabular}




\begin{tabular}{|c|c|c|}
\hline Felszerelés tömege & Használati tapasztalat & Felszerelés rendeltetése \\
\hline Teherbírás & Kompatibilitás & Felszerelés funkciója \\
\hline Önbiztosítás & Karbantarthatóság & Termék felhasználói utasítása \\
\hline & Extrém környezet & \\
\hline & Kézhasználat & \\
\hline & Alkalmazásba helyezés módja & \\
\hline
\end{tabular}

8. ábra Kötéltechnikai eszközök használhatóságára vonatkozó szempontok. Feltett kérdés: „Milyen biztonsági szempontok alapján választ kötéltechnikai felszerelést?” (Saját szerkesztés)

A tanulmány második részében a 8. ábra által összegzett eredményeket a Q-módszertan állításai közé feldolgoztam és szük szakértői körrel ismételten kontroláltam, a kapott eredményeket a jelen tanulmány második része tartalmazza.

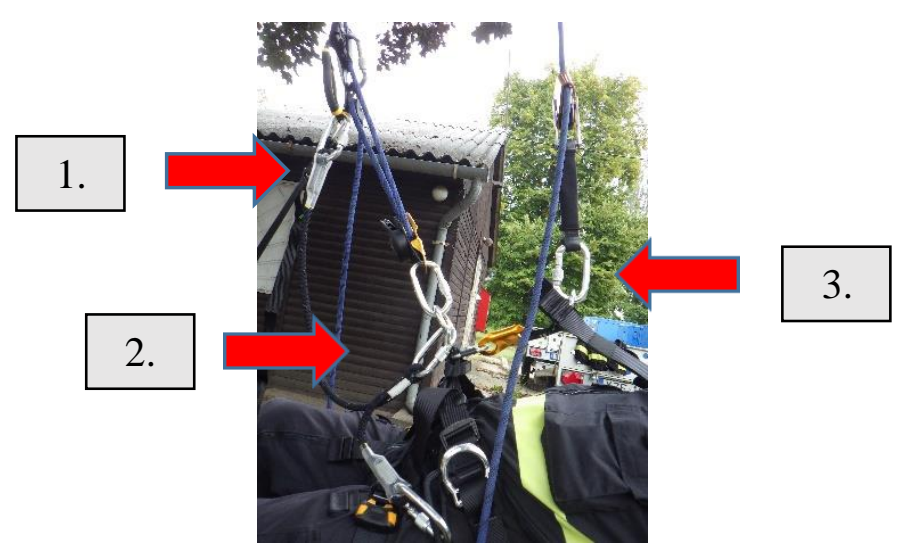

9. ábra Ereszkedőgép, mászógép, karabinerek összeállítása egy rendszerbe, mászás-ereszkedés biztonságos végrehajtásához, önbiztosítás alkalmazásával. Magyarázó ábra segítheti az eszközök biztonságos együtthasználhatóságának megértetését (1=mászógép, 2=ereszkedőgép, 3=karabiner; Fotó: HUNOR Mentőszervezet)

\section{ÖSSZEGZÉS}

A kötéltechnikai eszközök használatára vonatkozó felmérés eredményeinek ismeretében több statisztikai módszerrel megvizsgáltam a kérdőívre adott válaszok hátterét. Az eredmények értékelését követően szakmai döntés után 4 szempont alapján dolgoztam fel az 52 kérdéses kérdőív válaszait. A válaszadók összegzett értékítélete alapján a biztonság, a kezelhetőség és a gyártói utasítás hármasa mentén választanak kötéltechnikai felszerelést.

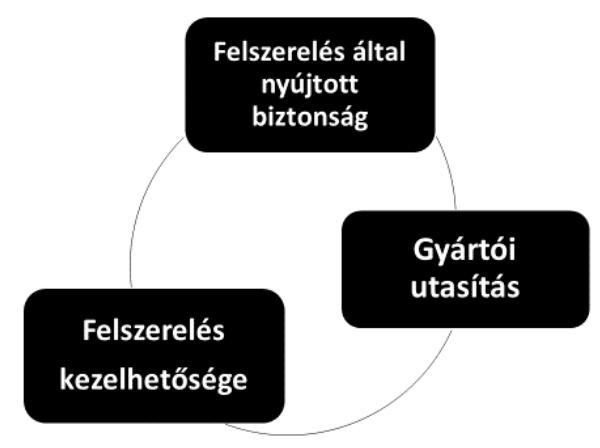

10. ábra Kötéltechnikai felszerelés választásában fontos tényezők hármasa (Saját szerkesztés)

A kötéltechnikai felszerelések felhasználói esetében erősíteni kell a biztonságos eszközhasználat szempontjait, más eszközzel történő együtthasználat kötelmeit, összetettebb eszközhasználat esetén a felszerelések alkalmazásba helyezésének alapvető szabályait [17]. 
Mentőszervezeteknek és a gyártóknak törekedni kell olyan szervezeti intézkedések meghozatalára, ahol senior szakértő vezetésével vagy oktatóval az elmélet igényes gyakorlás útján a felhasználók elsajátítják a kötéltechnikai alapfelszerelések együtthasználatát.

A tanulmányban a leíró statisztika alkalmazásával olyan szakmai javaslatokat sikerült megfogalmazni, amely a kötéltechnikai sport célú és kötéltechnikai-mentési tevékenység baleseti kockázatát csökkenthetjük. Felkészültek akkor lehetünk, ha az kötéltechnikai eszközök használatát rendszeresen gyakorolják a felhasználók, figyelembe veszik a gyártói, szervezeti utasításokat, nemzeti szabályozókat.

Összességében a kötéltechnikai eszközök balesetmentes használatában a felkészült felhasználó (egyén), a szigorú gyártói előírások, karbantartott felszerelés, eljárásrendek együttesen rendelkezésre állása szükséges. Fontos, hogy a résztvevők betartsák a munka- és balesetvédelmi, valamint a belső szervezeti elöírásokat [18]. „Az egyetemi szintü kutatások eredményeinek egyik fontos megjelenési formája az oktatás, képzés színvonalának növelése az elért tudományos eredmények folyamatos és fokozatos beintegrálása a tananyagba” [19].

A kötéltechnikai felszerelések használhatóságának feldolgozását a doktori kutatása keretében folytatni kívánom. A téma mélyebb feldolgozását és a további kutatási eredmények elemzését az International Journal of Occupational Safety and Ergonomics tudományos folyóiratban tervezem publikálni.

A tanulmány a második résszel dolgozza fel a kapott eredményeket Q-módszertan bevonásával, így teljessé téve a kötéltechnikai felszerelések biztonságos használatát célzó kutatást.

1. függelék Az Internetes kérdőív tematikus kérdései a speciális mentési felszerelések használatáról (saját szerkesztés)

\begin{tabular}{|c|c|c|}
\hline Sorsz. & $\begin{array}{l}\text { SPSS } \\
\text { kód }\end{array}$ & Kérdések a kérdöívben szereplő sorszámmal \\
\hline 1. & Desc01 & 1. Ereszkedőgép - Ön szerint mennyire közkedvelt az eszköz? \\
\hline 2. & Desc02 & $\begin{array}{l}\text { 2. Ereszkedőgép - Véleménye szerint az eszköz használata növeli-e a munkavégzés } \\
\text { biztonságát? }\end{array}$ \\
\hline 3. & Desc03 & 3. Ereszkedőgép - Az eszköz használata mennyire növeli az Ön teljesítményét? \\
\hline 4. & Desc04 & $\begin{array}{l}\text { 4. Ereszkedőgép - Mennyire növeli a kötéltechnikai müveletek hatékonyságát, kötéllel történő } \\
\text { együtthasználhatóságát? }\end{array}$ \\
\hline 5. & Desc05 & 5.1. Döntését mennyire befolyásolja: Ereszkedőgép márkája (gyártó)? \\
\hline 6. & Desc06 & 5.2. Döntését mennyire befolyásolja: Ereszkedőgép bolti ára? \\
\hline 7. & Desc07 & 5.3. Döntését mennyire befolyásolja: Ereszkedőgép színe? \\
\hline 8. & Desc08 & 5.4. Döntését mennyire befolyásolja: Ereszkedőgép kényelmes használata? \\
\hline 9. & Desc09 & 5.5. Döntését mennyire befolyásolja: Ereszkedőgép rendeltetése, funkciója? \\
\hline 10. & Desc10 & 5.6. Döntését mennyire befolyásolja: Ereszkedőgép használhatósága, kezelhetősége? \\
\hline 11. & Desc11 & $\begin{array}{l}\text { 5.7. Döntését mennyire befolyásolja: Ereszkedőgép által nyújtott biztonságosság, védelmi } \\
\text { képesség? }\end{array}$ \\
\hline 12. & Desc12 & 5.8. Döntését mennyire befolyásolja: Ereszkedőgép tömege? \\
\hline 13. & Desc13 & $\begin{array}{l}\text { 5.9. Döntését mennyire befolyásolja: Korábbi, ereszkedőgép használata során szerzett } \\
\text { tapasztalatok? }\end{array}$ \\
\hline 14. & Desc14 & 5.10. Döntését mennyire befolyásolja: Gyártói javaslat? \\
\hline 15. & Desc15 & $\begin{array}{l}\text { 5.11. Döntését mennyire befolyásolja: Ereszkedőgép más, meglévő eszközeivel való együtt } \\
\text { használat, kompatibilitás? }\end{array}$ \\
\hline 16. & Desc16 & $\begin{array}{l}\text { 5.12. Döntését mennyire befolyásolja: Ereszkedőgépre adott gyártói garancia ideje vagy } \\
\text { megléte? }\end{array}$ \\
\hline 17. & Desc17 & 5.13. Döntését mennyire befolyásolja: Ereszkedőgépre karbantarthatósága? \\
\hline
\end{tabular}




\begin{tabular}{|c|c|c|}
\hline 18. & Desc18 & 5.14. Döntését mennyire befolyásolja: Ereszkedőgép teherbírása? \\
\hline 19. & Desc19 & 5.15. Döntését mennyire befolyásolja: Használatba helyezés gyorsasága? \\
\hline 20. & $\operatorname{Desc} 20$ & 5.16. Döntését mennyire befolyásolja: Működőképesség piszkos-sáros körülmények között? \\
\hline 21. & $\operatorname{Desc} 21$ & 5.17. Döntését mennyire befolyásolja: Használat során szükséges-e külön önbiztosítás? \\
\hline 22. & Asc01 & 6. Mászógép - Ön szerint mennyire közkedvelt az eszköz? \\
\hline 23. & Asc02 & 7. Mászógép - Véleménye szerint az eszköz használata növeli-e a munkavégzés biztonságát? \\
\hline 24. & Asc03 & 8. Mászógép - Az eszköz használata mennyire növeli az Ön teljesítményét? \\
\hline 25. & Asc04 & $\begin{array}{l}\text { 9. Mászógép - Mennyire növeli a kötéltechnikai müveletek hatékonyságát, kötéllel történő } \\
\text { együtthasználhatóságát? }\end{array}$ \\
\hline 26. & Asc05 & 10.1. Döntését mennyire befolyásolja: Mászógép márkája (gyártó)? \\
\hline 27. & Asc06 & 10.2. Döntését mennyire befolyásolja: Mászógép bolti ára? \\
\hline 28. & Asc07 & 10.3. Döntését mennyire befolyásolja: Mászógép színe? \\
\hline 29. & Asc08 & 10.4. Döntését mennyire befolyásolja: Mászógép kényelmes használata? \\
\hline 30. & Asc09 & 10.5. Döntését mennyire befolyásolja: Mászógép rendeltetése, funkciója? \\
\hline 31. & Asc10 & 10.6. Döntését mennyire befolyásolja: Mászógép használhatósága, kezelhetősége? \\
\hline 32. & Ascl1 & $\begin{array}{l}\text { 10.7. Döntését mennyire befolyásolja: Mászógép által nyújtott biztonságosság, védelmi } \\
\text { képesség? }\end{array}$ \\
\hline 33. & Asc12 & 10.8. Döntését mennyire befolyásolja: Mászógép tömege? \\
\hline 34. & Asc13 & $\begin{array}{l}\text { 10.9. Döntését mennyire befolyásolja: Korábbi, Mászógép használata során szerzett } \\
\text { tapasztalatok? }\end{array}$ \\
\hline 35. & Asc14 & 10.10. Döntését mennyire befolyásolja: Gyártói javaslat? \\
\hline 36. & Asc15 & $\begin{array}{l}\text { 10.11. Döntését mennyire befolyásolja: Mászógép más, meglévö eszközeivel való együtt } \\
\text { használat, kompatibilitás? }\end{array}$ \\
\hline 37. & Asc16 & 10.12. Döntését mennyire befolyásolja: Mászógépre adott gyártói garancia ideje vagy megléte? \\
\hline 38. & Asc17 & 10.13. Döntését mennyire befolyásolja: Mászógép karbantarthatósága? \\
\hline 39. & Asc18 & 10.14. Döntését mennyire befolyásolja: Mászógép teherbírása? \\
\hline 40. & Asc19 & 10.15. Döntését mennyire befolyásolja: Használatba helyezés gyorsasága? \\
\hline 41. & Asc20 & 10.16. Döntését mennyire befolyásolja: Müködöképesség piszkos-sáros körülmények között? \\
\hline 42. & Asc21 & 10.17. Döntését mennyire befolyásolja: Használat során szükséges-e külön önbiztosítás? \\
\hline 43. & Asc22 & 10.18. Döntését mennyire befolyásolja: Mászógépek egykezes vagy kétkezes használatósága? \\
\hline 44. & Cara01 & 11. Döntését mennyire befolyásolja: A karabiner tömege? \\
\hline 45. & Cara02 & 12. Döntését mennyire befolyásolja: A karabiner terhelhetősége? \\
\hline 46. & Cara03 & 13. Döntését mennyire befolyásolja: A karabiner anyaga? \\
\hline 47. & Cara04 & 14. Döntését mennyire befolyásolja: A karabiner kezelhetőség? \\
\hline 48. & Cara05 & 15. Döntését mennyire befolyásolja: A karabiner zár típusa? \\
\hline 49. & Cara06 & 16. Döntését mennyire befolyásolja: A karabiner más felszereléssel történő együtt használata? \\
\hline 50. & Cara07 & 17. Döntését mennyire befolyásolja: A karabiner használat során szerzett korábbi tapasztalat? \\
\hline 51. & Cara08 & 18. Döntését mennyire befolyásolja: Karabiner gyártója, márkája? \\
\hline 52. & Cara9 & 19. Döntését mennyire befolyásolja: Karabiner beszerzési ára? \\
\hline
\end{tabular}

\section{KÖSZÖNETNYILVÁNÍTÁS}

Köszönettel tartozom Prof. Dr. Izsó Lajos professor emeritusnak, aki lehetővé tette a BME Pszichológia Doktori Iskolában a módszertani készségfejlesztés tantárgyak útján, a kísérleti statisztika, kísérlettervezés és statisztikai modellalkotás megismerését, valamint Prof. Dr. Szunyogh Gábor nyá. egyetemi docensnek, aki az Óbudai Egyetem Biztonságtudományi 
Doktori Iskola „Biztonsági kockázatok a természeti környezetben”c. tantárgy keretében a kötéltechnikához kapcsoló mentések kutatását támogatta.

\section{FELHASZNÁLT IRODALOM}

[1] ANTAL Ö., MUHORAY Á.: A földrengés katasztrófák által okozott szerkezeti omlásokkal kapcsolatos kutatás-mentési feladatok alkalmazott módszerei; Hadmérnök, IX. 2. (2014) 13. o.

[2] MUHORAY Á.: A polgári védelem helye és szerepe, feladata hazánkban a XXI. század elsö évtizedében; Polgári Védelmi Szemle, Budapest, 2010., 29-32. o.

[3] BÉRCZI L.: Az extrém körülmények közötti tüzoltói beavatkozások biztonságát növelö eszközrendszer fejlesztések az integrált katasztrófavédelem rendszerében; Doktori (PhD) értekezés (2014) 1-181. o., DOI azonosító: 10.17625/NKE.2014.010

[4] ALLEN, J. B., KENDRICK, D. T., UNDER, D. E. \&McCALL, M. A.: Arousal and attraction: A response-facilitation alternative to misattribution and negative reinforcement models Journal of Personality and Social Psychology, (1989). 57, pp. 261-270.

[5] KETSKEMÉTY L., IZSÓ L., KÖNYVES T.E.: Bevezetés az IBM SPSS Statistics programrendszerbe; Artéria Stúdió Kft. 2011.,157., 438. o.

[6] ZÁVOTI J.: Matematikai statisztikai elemzések 5., Kapcsolatvizsgálat: asszociáció, vegyes kapcsolat, korrelációszámitás. Varianciaanalízis (egyszeres osztályozás); Nyugat-magyarországi Egyetem (2010);

http://www.tankonyvtar.hu/hu/tartalom/tamop425/0027_MSTE5/ch01s05.html (letöltés: 2017.12.20.)

[7] STATISTIC SOLUTION: Correlation (Pearson, Kendall, Spearman); http://www.statisticssolutions.com/correlation-pearson-kendall-spearman/ (letöltés: 2017.12.20.)

[8] IZSÓ L.: Statisztikai elemzések, SPSS gyakorlatokat; egyetemi előadás (2017), BME APPI Ergonómia és Pszichológia Tanszék

[9] SZUNYOGH G.: Biztonsági kockázatok a természeti környezetben, egyetemi elöadás (2017) Óbudai Egyetem Bánki Donát Gépész és Biztonságtechnikai Mérnöki Kar

[10] LEARD STATISTICS: Mann-Whitney $U$ Test using SPSS Statistics; https://statistics.laerd.com/spss-tutorials/mann-whitney-u-test-using-spss-statistics.php (letöltve: 2017.12.20.)

[11] DEBRECENI EGYETEM: Esetelemzések az SPSS használatával; http://www.agr.unideb.hu/ baloghp/UzletiStat/korrelacio_spss_jegyzet.pdf (letöltve: 2017.12.20.)

[12] SZEGEDI TUDOMÁNYEGYETEM; Spearman-féle rangkorreláció; http://www.math.u-szeged.hu/ ngyj/spss/spearman.pdf (letöltve: 2017.12.20.)

[13] EÖTVÖS LORÁND TUDOMÁNYEGYETEM: Mann-Whitney próba; http://kognitiv.elte.hu/statisztika/index.php/Mann-Whitney_pr\%C3\%B3ba (letöltés: 2018.07.14.) 
[14] ÁLLATORVOSTUDOMÁNYI EGYETEM: Esetelemezés az SPSS alkalmazásával; http://www2.univet.hu/users/biostatphd/alapok/07-hipotezisvizsgalat.pdf $\quad$ (letöltés: 2017.12.20)

[15] JACKOVICS P.: Kötéltechnikai mentési alapfelszerelések rendeltetésének értékelése; Védelem Tudomány: Katasztrófavédelmi Online Tudományos folyóirat; 2016. (2.) pp. 556-586. o.

[16] JACKOVICS P.: A barlangi balesetek és mentések adatainak elemzése; Hadmérnök, XI. 3. (2016) 57-74. o.

[17] JACKOVICS P.: Standard of operation for cave rescue in Hungary; International Fire Fighter, 2016 (9) pp. 84-86

[18] JACKOVICS P.: New Professional Guidelines in Hungary; FireRescueMagazine2016. (11) pp. 50-56

[19] BLESZITY J., FÖLDI L., HAIG Zs., NEMESLAKI A., RESTÁS Á.: Müszaki kutatások és hatékony kormányzás, Hadmérnök, XI. 3. (2016) 223. o. 